\title{
Faktor-Faktor yang Mempengaruhi Kinerja Keuangan Usaha Koperasi (SHU) di Koperasi Unit Desa (KUD) Harapan Maju Desa Petaling Jaya Kecamatan Batang Cenaku Kabupaten Indragiri Hulu
}

\author{
R Marwan Indra Saputra ${ }^{1^{*}}$, Aris Triyono ${ }^{2}$ \\ ${ }^{1,2}$ Program Studi Manajemen, Sekolah Tinggi Ilmu Ekonomi Indragiri (STIE-I) Rengat \\ *Correspondence email: marwan@ stieindragiri.ac.id, ${ }^{2}$ arist@ stieindragiri.ac.id
}

\begin{abstract}
This research is at the Village Cooperative Unit (KUD) Harapan Maju Petaling Jaya Village, Batang Cenaku District, Indragiri Hulu. This research used quantitative research, where the results of the analysis are presented in the form of figures which are then explained and interpreted in a description. The data used by the author in this study is secondary data and the research method used is descriptive method. From the results of the research it shows that: Own capital has no effect and is insignificant, the volume of business has a significant effect, assets have no effect and are significant for the acquisition of Remaining Operations (SHU), own capital, business volume and assets together affect the acquisition Remaining Operating Results (SHU) and there are other variables that affect the acquisition of Remaining Operations (SHU). Which is not examined in this study.
\end{abstract}

Keywords: Own capital, Business Volume, Assets and Remaining Operations.

\section{Pendahuluan}

Koperasi merupakan gerakan ekonomi rakyat yang bertujuan untuk meningkatkan kesejahteraan masyarakat yang berlandaskan kegiatannya pada prinsip-pinsip koperasi. Sebagai gerakan, koperasi menjunjung tinggi nilai-nilai kebersamaan dan kerjasama antar anggotanya sangat diperlukan untuk mewujudkan tujuan utamanya, yaitu meningkatkan kesejahteraan para anggotanya dan kemakmuran masyarakat (Jajang, 2011). Untuk menumbuh kembangkan koperasi diperlukan adanya keuntungan yang sering disebut dengan Sisa Hasil Usaha (SHU). Hal ini disebabkan karena Sisa Hasil Usaha sebagai salah satu indikator untukmenentukan keberhasilan suatu koperasidalam meningkatkan kesejahteraan anggotanya.

Sisa Hasil Usaha (SHU) Koperasi adalah sebagai selisih dari seluruh pemasukan atau penerimaan total (Total Revenue) atau biasa dilambangkan dengan TR dengan biaya-biaya atau biaya total (Total Cost) dengan lambang TC dalam satu tahun waktu. Untuk mengetahui perkembangan jumlah Sisa Hasil Usaha (SHU) yang diperoleh Koperasi Unit Desa Harapan Maju Petaling Jaya Batang Cenaku Kabupaten Indragiri Hulu selama sepuluh tahun terakhir dapat dilihat pada Tabel 1., yang penulis sajikan berikut ini :

Tabel 1

Perkembangan Jumlah Sisa Hasil Usaha (SHU) KoperasiUnit Desa Harapan Maju Petaling Jaya, tahun 2009-2018 (Dalam Rupiah).

\begin{tabular}{ccrr}
\hline No & Tahun & Sisa Hasil Usaha (SHU) & \multicolumn{2}{c}{ Pertumbuhan } \\
\hline 1 & 2009 & $206,630,911$ & - \\
2 & 2010 & $441,363,171$ & $234,732,260$ \\
3 & 2011 & $445,663,181$ & $4,300,010$ \\
4 & 2012 & $423,868,048$ & $-21,795,133$ \\
5 & 2013 & $268,437,136$ & $-155,430,912$ \\
6 & 2014 & $285,163,192$ & $16,726,056$ \\
7 & 2015 & $126,675,652$ & $-158,487,540$ \\
8 & 2016 & $212,553,548$ & $85,877,896$ \\
9 & 2017 & $267,174,310$ & $54,620,762$ \\
10 & 2018 & $253,072,913$ & $-14,101,397$ \\
Total & & $2,926,302,052$ & - \\
Rata-rata & & $292,630,205$ & - \\
\hline
\end{tabular}

Sumber: KUD Harapan Maju Petaling Jaya, 2019.

Data tabel diatas bahwa pertumbuhan Sisa Hasil Usaha (SHU) selamasepuluh tahun 2009-2018, mengalami fluktuasi pertumbuhan, dan bahkan ada yang minus, perkembangan/ pertumbuhan Sisa Hasil Usaha (SHU) di pengaruhi oleh beberapa faktor diantaranya modal sendiri, volume usaha dan aset, untuk itu untuk mengetahui apakah berpengaruh dan tidaknya faktor tersebut berdasarkan dari beberapa penelitian terdahulu yang dilakukanoleh R Neny Kusumadewi (2014) hasil penelitian tidak ada pengaruh yang signifikan modal sendiri terhadap SHU. Wayan Wirastini et al (2018) 
hasil penelitian modal sendiri berpengaruh positif dan aset tidak berpengaruh terhadap SHU. Gaviota Gilda Putri et al (2016) dengan hasil penelitian modal sendiri, modal luar, dan tingkat perputaran piutang berpengaruh positif signifikan namun volume usaha tidak berpengaruh positif signifikan terhadap SHU. Tujuan penelitian ini adalah untuk mengetahui pengaruh (1) modal sendiri, volume usaha dan aset secara simultan berpengaruh signifikan terhadap kinerja keuangan usaha koperasi (SHU); (2) modal sendiri, secara parsialberpengaruh signifikan terhadap kinerja keuangan usaha koperasi (SHU); (3) volume usaha, secara parsialberpengaruh signifikan terhadap kinerja keuangan usaha koperasi (SHU); (4) aset, secara parsialberpengaruh signifikan terhadap kinerja keuangan usaha koperasi (SHU)

\section{Tinjauan Pustaka}

\section{Kinerja Keuangan Koperasi (SHU)}

SHU adalah laba atau keuntungan yang diperoleh dari menjalankan usaha sebagaimana layaknya sebuah perusahaan SHU tersebut merupakan hasil akhir dari komponen-komponen yang menghasilkan dikurangi dengan jumlah komponen-komponen biaya, (Andjar Pachta W dkk, 2005). Ditinjau dari aspek ekonomi manajerial, SHU koperasi adalah selisih dari seluruh pemasukan atau penerimaan total (total revenue) dengan biaya-biaya atau total (total cost) dalam satu tahun buku, (Arifin Sitio dan Halomoan Tambunan, 2001).

Bila ditinjau menurut UU No 25 Tahun 1992 tentang perkoperasian bab IX pasal 45 adalah sebagai berikut: (a) Sisa Hasil Usaha (SHU) pendapatan koperasi yang diperoleh dalam satu tahun buku dikurangi dengan biaya, penyusutan dan kewajiban lain termasuk pajak dalam tahun buku yang bersangkutan; (b) Sisa Hasil Usaha (SHU) setelah dikurangi dana cadangan, dibagikan kepada anggota sebanding jasa usaha yang dilakukan oleh masing-masing anggota dengan koperasi serta digunakan untuk keperluan pendidikan perkoperasian dan keperluan koperasi sesuai dengan keputusan Rapat Anggota; (c) Besarnya pemupukan modal dana cadangan ditetapkan dalam Rapat Anggota; dan (d) Penetapan besarnya pembagian kepada para anggota dan jenis serta jumlahnya ditetapkan oleh Rapat Anggota sesuai dengan AD/ART koperasi.

Sisa Hasil Usaha (SHU) Koperasi marupakan pendapatan koperasi yang diperoleh dalam satu tahun buku dikurangi dengan biaya, penyusutan dan kewajiban lainnya termasuk pajak dalam tahun buku yang bersangkutan (Dewik, et. al, 2015). Sisa Hasil Usaha (SHU) adalah pendapatan koperasi yang diperoleh dalam waktu satu tahun buku dikurangi dengan biaya, penyusutan, dan kewajiban lainnya termasuk pajak dalam tahun buku yang bersangkutan (UU No.25 Tahun 1992 Pasal 1 dan 2).

\section{Faktor-faktor yang Mempengaruhi Sisa Hasil Usaha (SHU)}

Sesuai sambutan Menteri Negara Koperasi dan usaha Kecil Menengah (31 agustus 2005), faktor-faktor yang mempengaruhi Sisa Hasil Usaha (SHU) koperasi dicerminkan oleh indikator keuangan koperasi seperti, modal sendiri, modal luar, volume usaha dan sisa hasil usaha koperasi.

a. Modal Sendiri, adalah modal yang berasal dari perusahaan itu sendiri (cadangan, laba) atau berasal dari pengambilan bagian, peserta atau pemilik (modal saham, modal peserta, dll. (Riyanto; 2001:21). Pada dasarnya modal sendiri adalah modal yang berasal dari pemilik perusahaan dan yang tertanam didalam perusahaan untuk waktu yang tidak tentu lamanya (Riyanto, 2001)

b. Volume Usaha, adalah total nilai penjualan atau penerimaan dari barang dan jasa pada suatu periode atau tahun buku yang bersangkutan (Sitio, 2001). Dengan demikian volume usaha koperasi adalah akumulasi penerimaan barang dan jasa sejak awal tahun buku sampai dengan akhir tahun buku. Aktivitas ekonomi pada hakekatnya dapat dilihat dari besarnya volume usaha koperasi tersebut. Kegiatan atau usaha yang dilakukan oleh koperasi bisa memberikan manfaat yang sebesar-besarnya terutama bagi anggota koperasi dan masyarakat pada umumnya. Volume usaha atau pendapatan dari sebuah koperasi terdapat beberapa karakteristik sebagai berikut: pendapatan yang timbul dari transaksi penjual produk atau penyerahan jasa kepada anggota dan bukan anggota dan pendapatan tertentu yang realisasi penerimaannya masih tergantung pada persyaratan/ketentuan yang diterapkan.

c. Aset, menurut Munawir (2007) aktiva dapat diklasifikasikan menjadi dua bagian utama yaitu aktiva lancar dan aktiva tidak lancar.Aset adalah manfaat ekonommasa depan yang cukup pasti yang diperoleh atau dikuasai oleh perusahaan sebagai akibat dari peristiwa masa lalu, yang dimaksud manfaat ekonomi masa depan adalah potensi aset tersebut untuk menghasilkan arus kas dan setara kas kepada perusahaan, baik secara langsung maupun tidak langsung (Sodikin dan Riyono, 2012).

\section{Hipotesis}

H1:Di duga Modal sendiri berpengaruh terhadap Kinerja keuangan usaha koperasi (SHU).

H2:Di duga Volume usaha berpengaruh terhadap Kinerja keuangan usaha koperasi (SHU).

H3: Di duga Aset berpengaruh terhadap Kinerja keuangan usaha koperasi (SHU).

H4:Di duga Modal sendiri, Volume usaha dan Aset berpengaruh terhadap Kinerja keuangan usaha koperasi (SHU). 
R Marwan Indra Saputra dan Aris Triyono, Faktor-Faktor yang Mempengaruhi Kinerja Keuangan Usaha Koperasi (SHU) di Koperasi Unit Desa (KUD) Harapan Maju Desa Petaling Jaya Kecamatan Batang Cenaku Kabupaten Indragiri Hulu

\section{Metode}

Tempat Penelitian; Koperasi Unit Desa Harapan Maju, Petaling Jaya, Batang Cenaku, Kabupaten Indragiri Hulu. Jenis dan Sumber Data; jenis data kuantitatif sumber data yang digunakan adalah data sekunder yaitu data yang diperoleh berupa laporan keuangan dari Buku laporan Rapat Anggota Tahunan (RAT) milik Koperasi Unit DesaHarapan Maju, Petaling Jaya, Batang Cenaku, Kabupaten Indragiri Hulu pada setiap tahunnya sesuai dengan data yang penulis butuhkan dan gunakan dalam penelitian ini.Teknik Pengumpulan Data;Wawancara dan Studi Pustaka.

\section{Analisis Data}

Pengujian hipotesis menggunakan analisis regresi berganda dengan persamaan strukturalnya sebagai berikut; $\mathrm{Y}=$ $\mathrm{a}+\mathrm{b}_{1} \mathrm{X}_{1}+\mathrm{b} 2 \mathrm{X}_{2}+\mathrm{b}_{3} \mathrm{X}_{3}$

Dimana: $\mathrm{X}_{1}=$ Modal sendiri; $\mathrm{X}_{2}=$ Volume usaha; $\mathrm{X}_{3}=$ Aset; $\mathrm{Y}=\mathrm{SHU} ; \mathrm{b}_{1}-\mathrm{b}_{3}=$ koefisien regresi dari $\mathrm{X}_{1}, \mathrm{X}_{2}$, dan $\mathrm{X}_{3}$.Semua perhitungan mengunakan SPSS 21.

\section{Hasil}

Tabel 2

Coefficients

\begin{tabular}{|l|r|r|r|r|r|}
\hline \multirow{2}{*}{ Model } & \multicolumn{2}{|c|}{ Unstandardized Coefficients } & Standardized Coefficients & \multirow{2}{*}{$\mathrm{t}$} & \multirow{2}{*}{ Sig. } \\
\cline { 2 - 6 } & \multicolumn{1}{|c|}{$\mathrm{B}$} & \multicolumn{1}{|c|}{ Std. Error } & Beta & -0.058 & 0.955 \\
(Constant) & -8.146 & 139.516 & -0.629 & -0.574 & 0.587 \\
Modal Sendiri & -0.06 & 0.105 & 3.778 & 3.168 & 0.019 \\
Volume Usaha & 1.012 & 0.32 & -3.623 & -2.61 & 0.040 \\
Aset & -0.063 & 0.024 & & & \\
\hline
\end{tabular}

Sumber: data olahan

Berdasarkan tabel diatas dapat diketahui persamaan regresinya sebagai berikut; $\mathrm{Y}=-8.146-0,060 \mathrm{X} 1+1.012$ X2 - $0,063 \mathrm{X} 3+$ ei.

Analisis persamaan regresi berganda tersebut sebagai berikut :

1. Nilai constant negatif diasumsikan bahwa tanpa ditambah variabel modal sendiri, volume usaha dan aset, maka nilai SHU akan mengalami penurunan atau pengurangan sebesar $-8,146$.

2. Apabila X1 (modal sendiri) mengalami peningkatan sebesar 1 satuan dengan asumsi volume usaha dan aset dianggap tetap maka SHU akan berkurang sebesar -0,060.

3. Apabila X2 (volume usaha) mengalami peningkatan sebesar 1 satuan dengan asumsi modal sendiri dan aset dianggap tetap maka SHU akan bertambah sebesar 1,012.

4. Apabila X3 (aset) mengalami peningkatan sebesar 1 satuan dengan asumsi modal sendiri dan volume usaha tetap maka SHU akan berkurang sebesar -0,063.

5. Apabila X1 bernilai $0, \mathrm{X} 2$ bernilai 0 dan X3 bernilai 0 , maka SHU besarnya sama dengan nilai konstan. Itu berarti SHU dipengaruhi oleh faktor lain diluar variabel bebasnya.

Tabel 3

Model Summary

\begin{tabular}{|l|lr|rr|}
\hline Model & R & R Square & Adjusted R Square & Std. Error of the Estimate \\
\hline 1 & $.855^{\text {a }}$ & 0.731 & 0.596 & 68.89799 \\
\hline
\end{tabular}

Sumber: data olahan

Tabel diatas menunjukkan bahwa koefisien korelasi ( $R$ ) dan koefisien determinan ( $R$ square). Nilai $R$ menerangkan tingkat hubungan antar variabel-variabel independen $(\mathrm{X})$ dengan variabel dependen (Y). Dari hasil olahan data di peroleh nilai koefisien korelasi sebesar 0,855 artinya hubungan antara variabel modal sendiri (X1), volume usaha (X2) dan Aset (X3) terhadap variabel perolehan SHU (Y) dalam kategori sangat kuat. R square menjelaskan seberapa besar kekuatan pengaruh variabel bebas tehadap variabel terikat dapat diketahui dari besarnya nilai koefisien determinan (R2), yang berada antara nol dan satu. Variabel Y yang disebabkan oleh X, dari hasil perhitungan diperoleh R2 sebesar 0,731 atau 73,1\% artinya 73,1\% perolehan SHU dipengaruhi oleh ketiga variabel bebas modal sendiri, volume usaha dan aset. Sedangkan siswanya $26,9 \%$ dipengaruhi oleh faktor-faktor lain diluar model yang tidak diteliti dalam penelitian ini 
R Marwan Indra Saputra dan Aris Triyono, Faktor-Faktor yang Mempengaruhi Kinerja Keuangan Usaha Koperasi (SHU) di Koperasi Unit Desa (KUD) Harapan Maju Desa Petaling Jaya Kecamatan Batang Cenaku Kabupaten Indragiri Hulu

Uji Hipotesis

\begin{tabular}{|c|c|c|c|c|c|c|}
\hline & \multicolumn{6}{|c|}{$\begin{array}{l}\text { Tabel } 4 . \\
\text { ANOVA }\end{array}$} \\
\hline & Model & Sum of Squares & $\mathrm{df}$ & Mean Square & $\mathrm{F}$ & Sig. \\
\hline \multirow{3}{*}{1} & Regression & 77203.999 & 3 & 25734.666 & 5.421 & $.038^{\mathrm{b}}$ \\
\hline & Residual & 28481.601 & 6 & 4746.934 & & \\
\hline & Total & 105685.6 & 9 & & & \\
\hline
\end{tabular}

Sumber: data olahan

Tabel diatas menunjukan bahwa nilai $\mathrm{F}$ hitung adalah sebesar 5,421, sedangkan nilai $\mathrm{F}$ tabelnya adalah 5.140 (df $1=4-1=3$ dan df2=10-3-1=6). Selain itu nilai signifikansinya adalah sebesar 0,04 lebih kecil pada taraf signifikans (a) 0,05 . Karena nilai $\mathrm{F}$ hitung $>\mathrm{F}$ tabel $(5,421>5,140)$ dan nilai signifikans lebih kecil dari taraf singnifikans (a) 0,05 ( $0,04<0,05$ ), maka hipotesis pertama Ho duterima dan Ha ditolak, artinya Modal sendiri, Volume usaha dan Aset secara Simultan berpengaruh signifikans terhadap perolehan Sisa Hasil Usaha (SHU)

Hasil uji parsial (uji t) pada tabel dapat dijelaskan sebagai berikut :

1. Untuk variabel modal sendiri (X1) diperoleh t hitung sebesar -0,574 sedangkan t tabelnya adalah sebesar, 2,447. Nilai signifikan 0,587. lebih besar dari taraf signifikans 0,05 . Karena nilai $t$ hitung $<\mathrm{t}$ tabel $(-0,574<2.447)$ dan nilai signifikan lebih besar dari tarif signifikans (a) 0,05 (0,587 > 0,05), maka hipotesis $\mathrm{H} 1$ adalah Ho diterima Ha ditolak, artinya Modal sendiri secara parsial tidak berpengaruh terhadap Perolehan Hasil Usaha (SHU)

2. Untuk variabel Volume usaha (X2) diperoleh t hitung sebesar 3.168. sedangkan t tabelnya adalah sebesar, 2.447. Nilai signifikan 0,02lebih kecil dari taraf signifikans 0,05 . Karena nilai t hitung > t tabel $(3,168>2.447)$ dan nilai signifikan lebih kecil dari tarif signifikans (a) 0,05 (0,02<0,05), maka hipotesis H1 adalah Ho diterima Ha ditolak, artinya Volume usaha secara parsial berpengaruh terhadap Perolehan Hasil Usaha (SHU)

3. Untuk Aset (X3) diperoleh thitung sebesar -2,610 sedangkan $t$ tabelnya adalah sebesar, 2.447. Nilai signifikan 0,04. lebih kecil dari taraf signifikans 0,05 . Karena nilai $t$ hitung $<\mathrm{t}$ tanel $(-2,610<2.447)$ dan nilai signifikan lebih kecil dari tarif signifikans (a) 0,05 $(0,04<0,05)$, maka hipotesis H1 adalah Ho diterima Ha ditolak, artinya Aset secara parsial berpengaruh negatif signifikans terhadap Perolehan Hasil Usaha (SHU).

Pengaruh modal sendiri terhadap SHU, dalam penelitian ini menyatakan modal sendiri tidak berpengaruh dan tidak signifikan terhadap SHU.Sejalan dengan penelitian terdahulu yang dilakukanoleh R Neny Kusumadewi (2014) hasil penelitian tidak ada pengaruh yang signifikan modal sendiri terhadap SHU. Pengaruh volume usaha terhadap SHU, Dalam penelitian ini volume usaha berpengaruh signifikan SHU Koperasi. Pengaruh volume usaha terhadap SHU sangat besar apabila penggeolaan koperasi yang dilakukan lebih baik dan efektif.Hasil penelitian ini sejalan dengan penelitian oleh Hosekin (2015), Jabar (2014), Raharjo (2014),yang menyatakan bahwa volume usaha berpengaruh positif dan signifikan terhadap SHU Koperasi. Pengaruh Aset terhadap SHU, Aset tidak berpengaruh dan signifikan terhadap perolehan Sisa Hasil Usaha (SHU)hal ini berarti bahwa koperasi kurangmampu mengelola asetnya, makakemampuan koperasi dalam mencapaiSisa Hasil Usaha (SHU) akan kurangmaksimal. Pengaruh Modal sendiri, Volume usaha dan Aset terhadap Sisa Hasil Usaha (SHU), Berdasarkan hasil penelitian Modal sendiri, Volume usaha dan Aset secara bersama-sama mempengaruhi perolehan Sisa Hasil Usaha (SHU)secara bersama-sama atau simultan dari Modal Sendiri, Volume usaha dan Aset, terhadap SHU. Dengan Modal Sendiri, Volume usaha dan Aset,yang tinggi, maka koperasi akan memperoleh Sisa Hasil Usaha (SHU) yang tinggi sehingga dapat meningkatkan keuntungan usahanya. Hasil penelitian ini sejalan dengan pernyataan teoritik dari Andjar Pachta W, dkk (2005), faktor-faktor yangmempengaruhi SHU terdiri dari dua faktor yaitu faktor dalam dan faktor luar. Faktor dalam terdiri dari partisipasi anggota, jumlah modal sendiri, aset, kinerja pengurus, volume usaha, kinerja manajer serta kinerja karyawan. Faktor luarnya terdiri dari modal pinjaman dari luar, perilaku konsumen luar selain anggota dan pemerintah.Dengan demikian besarnya SHU yang diperoleh koperasi setiap tahunnya merupakan indikator keberhasilan pengelolaan koperasi. SHU mempunyai hubungan yang sangat erat dengan Modal Sendiri, Total Aset, dan Volume Usaha.

\section{Simpulan}

Berdasarkan analisis data dan pembahasan hasil penelitian bahwa; Modal sendiri tidak berpengaruh dan tidak signifikan terhadap perolehan Sisa Hasil Usaha (SHU),Volume usaha berpengaruh signifikan terhadap perolehan Sisa Hasil Usaha (SHU), Aset tidak berpengaruh dan signifikan terhadap perolehan Sisa Hasil Usaha (SHU), Modal sendiri, Volume usaha dan Aset secara bersama-sama mempengaruhi perolehan Sisa Hasil Usaha (SHU) 
R Marwan Indra Saputra dan Aris Triyono, Faktor-Faktor yang Mempengaruhi Kinerja Keuangan Usaha Koperasi (SHU) di Koperasi Unit Desa (KUD) Harapan Maju Desa Petaling Jaya Kecamatan Batang Cenaku Kabupaten Indragiri Hulu

\section{Daftar Pustaka}

Dewik Ni Kadek dan Jember I made. 2016. Faktor-faktor yang mempengaruhi sisa hasil usaha (SHU) Koperasi Simpan Pinjam di Kecamatan Kuta Utara Kabupaten Badung. E-Jurnali Epi Unud, 5(7) : 729-753.

Dedeh Sri Sudaryanti1, N. S. 2017. Pengaruh Jumlah Anggota, Modal Luar, Dan Total Asset Terhadap Sisa Hasil Usaha (Studi Empiris Pada Koperasi Simpan Pinjam Di Kota Tasikmalaya) Dedeh. Ekspektra: Jurnal Bisnis Dan Manajemen, 1, 156-172.

Jajang, W. Mahri. 2011.Pelayanan dan ManfaatKoperasi Dan Pengaruhnya Terhadap Partisipasi Anggota (Studi KasusPada KoperasiProdusen TahuTempeKabupaten Tasik Malaya).Ekonomi Koperasi, Bandung:UniversitasPendidikan Indonesia.

Munawir. 2007. Analisis Laporan Keuangan, Yogyakarta: Liberty Raharjo, Yori Setia. 2014. Analisis Faktor-Faktor yang Mempengaruhi Sisa Hasil Usaha Koperasi Serba Usaha di Kabupaten Sukoharjo. Naskah Publikasi

Munir, Misbachul. 2011. Analisis Tingkat Kesehatan Koperasi Pada Koperasi Simpan Pinjam "Cendrawasih" Kecamatan Gubug Tahun Buku 2011. Jurnal Ekonomi. Sekolah Tinggi Ilmu Ekonomi Widya Manggala. Supriyanto (2015:130-131)

Niam, M. F. 2017. Pengaruh Modal Sendiri, Modal Asing , Dan Volume Usaha Terhadap Sisa Hasil Usaha Pada Koperasi Unit Desa (KUD) Di Kabupaten Malang Periode 2013-2017. E - Jurnal Riset Manajemenprodi Manajemen, 34-43.

Putri, Gaviota Gilda, Bambang Sunarko, R. W. 2016. Analisis Pengaruh Modal Sendiri, Modal Luar, Volume Usaha, dan Tingkat Perputaran Piutang Terhadap Sisa Hasil Usaha. Http://Jp.Feb.Unsoed.ac.id, Vol.23 No., 1-14.

Pachta, Andjar, dkk. 2009. Manajemen Koperasi: Teori dan Praktik. Yogyakarta: Graha Ilmu. Jurnal, Erni Unggul Sedya Utami.

Riyanto, Bambang. 2001. Dasar-Dasar Pembelanjaan Perusahaan. Edisi 4. Yogyakarta: BPFE

R. Neny Kusumadewi, S. 2014. Pengaruh Modal Sendiri Terhadap Perolehan Sisa Hasil Usaha Pada Kpri Di Kabupaten Majalengka (Studi Kasus Pada Kpri Di Kabupaten Majalengka). E- Maksi Jurnal Ilmiah Manajemen \& Akuntansi, Volume 1 N, 65-89.

Suputra, I. G., Putu, G., Jana, A., \& Cipta, W. 2016. Pengaruh Modal Sendiri , Total Aset , Dan Volume Usaha Terhadap Sisa Hasil Usaha ( Shu ) Pada Koperasi Simpan. E-Journal Bisma Universitas Pendidikan Ganesha, 4(1).

Sitio, Arifin dan Halomoan Tamba. 2001. Koperasi: Teori dan Praktik. Jakarta: Erlangga.

Sodikin SS dan Riyono BA. 2012. Akuntansi Pengantar 1. Yogyakarta: Sekolah Tinggi Ilmu Manajemen YKPN.

Undang Undang Republik Indonesia No.25 tahun 1992 tentang Perkoperasian Undang-Undang

Wirastini, W., \& Fariantin, B. D. P. E. 2018. Pengaruh Modal Sendiri Dan Aset Terhadap Perolehan Sisa Hasil Usaha Pada Koperasi Simpan Pinjam Swastika Mataram. Jurnal Kompetitif: Media Informasi Ekonomi Pembangunan, Manajemen Dan Akuntansi, Vol. 4 No.(25), 182-195.

Yuliastuti, I. A. N., \& Susandya, A. A. P. G. B. A. 2018. Faktor-Faktor Yang Mempengaruhi Sisa Hasil Usaha Koperasi Di Kota Denpasar. Piramida, XIV(1), 59-66. 